\title{
Pengaruh Lingkungan Sekolah Dan Faktor Psikologi Peserta Didik Terhadap Hasil Belajar Mata Pelajaran Ekonomi Kelas XI IPS SMA Negeri 1 Sumberrejo
}

\author{
Ahmad Syafiuddin Zuhri \\ Program Studi S1 Pendidikan Ekonomi, Fakultas Ekonomi, Universitas Negeri Surabaya \\ Email: ahmad.17080554002@mhs.unesa.ac.id
}

\begin{abstract}
ABSTRAK
Penelitian ini bertujuan untuk mengetahui pengaruh lingkungan sekolah dan faktor psikologi peserta didik terhadap hasil belajar mata pelajaran ekonomi kelas XI IPS SMA Negeri 1 Sumberrejo.Jenis penelitian ini adalah penelitian kuantitatif dengan menggunakan metode korelasi. Populasi penelitian ini adalah seluruh peserta didik kelas XI IPS SMA Negeri 1 Sumberrejoyang berjumlah 135 peserta didik. Pengumpulan data menggunakan kuesioner dan nilai akhir semester peserta didik kelas XI IPS. Teknik analisis data dalam penelitian ini menggunakan analisis regresi linier berganda.Berdasarkan hasil penelitian maka diperoleh kesimpulan : 1) Terdapat pengaruh dari lingkungan sekolah terhadap hasil belajar mata pelajaran ekonomi kelas XI IPS SMA Negeri 1 Sumberrejo.Lingkungan sekolah merupakan salah satu faktor eksternal yang berpengaruh terhadap hasil belajar peserta didik, sehingga perlu diperhatikan keadaan lingkungan sekolah agar memberikan motivasi bagi peserta didik dalam meningkatkan hasil belajarnya; 2) Terdapat pengaruh faktor psikologi terhadap hasil belajar mata pelajaran ekonomi kelas XI IPS SMA Negeri 1 Sumberrejo. Sehingga salah satu faktor intern yang harus lebih diperhatikan peserta didik agar mendapatkan hasil belajar yang baik adalah faktor psikologi.
\end{abstract}

Kata Kunci: Lingkungan Sekolah, Faktor Psikologi, dan Hasil Belajar

\section{PENDAHULUAN}

Salah satu upaya untuk dapat mencerdaskan kehidupan suatu bangsa adalah dengan memperhatikan kualitas pendidikannya. Perubahan pola pendidikan yang diakibatkan oleh pesatnya kemajuan teknologi mengharuskan semua pihak seperti guru, peserta didik, dan orang tua untuk berangsur-angsur mengikuti guna mencapai kualitas serta hasil belajar yang maksimal. Menurut Utama et al. (2015)segala perubahan yang dialami oleh seseorang sebagai akibat dari kegiatan pembelajaran itulah yang dinamakan dengan hasil belajar. Sedangkan menurut Dewi \& Marwan (2019)hasil belajar dengan kegiatan belajar merupakan satu kesatuan yang saling berkaitan sebab keduanya memiliki hubungan saling mempengaruhi dimana hasil belajar dipengaruhi oleh pembelajaran yang dilakukan. Hasil belajar digunakan oleh guru sebagai tolok ukur untuk mencapai tujuan akhir dari proses pendidikan. Rohwati (2012) mengatakan bahwa untuk dapat mengetahui kesuksesan yang didapat peserta didik selama pembelajaran berlangsung serta sejauh mana tingkat keberhasilan guru dalam menerapkan sistem pembelajaran maka tolok ukurnya adalah dengan melihat bagaimana hasil akhir yang didapat oleh peserta didik.

Slameto (2010)berpendapat dalam bukunya bahwa faktor yang berpengaruh terhadap hasil belajar dapat dikelompokkan kedalam dua golongan saja yaitu faktor dari luar atau ekstern dan faktor dari dalam atau intern. Yang masuk kedalam faktor ekstern diantaranya seperti faktor dari keluarga, masyarakat, dan sekolah. Sedangkan yang masuk kedalam faktor intern sendiri meliputi faktor kelelahan, jasmaniah, dan psikologis. Pada beberapa penelitian 
terdahulu telah dibahas mengenai beberapa faktor-faktor yang tergolong faktor eksternal yang memiliki pengaruh terhadap hasil belajar, namun dari semua faktor hanya beberapa faktor saja yang dibahas. Seperti penelitian oleh Araimi \& Fitra (2015) mengatakan bahwahasil belajar dipengaruhi secara positif oleh lingkungan keluarga yang artinya bahwa semakin positif pengaruh yang diberikan keluarga terhadap peserta didik itu artinya dapat meningkatkan hasil belajar yang diperoleh. Demikian jugahasil penelitian yang didapat olehKhafid \& Suroso (2007)mengatakan bahwasanya hasil akhir proses pembelajaran yang didapatkan peserta didik dipengaruhi oleh lingkungan keluarga dan disiplin belajar. Berdasar dari kedua penelitian tersebut diketahui bahwa belum ada yang membahas mengenai lingkungan sekolah, sedangkan Utama et al. (2015) mengatakan bahwa hasil akhir dari proses pembelajaran yang didapat peserta didik salah satunya dipengaruhi oleh faktor eksternal yaitu lingkungan sekolah.

Selain faktor eskternal, Slameto (2010)juga mengemukakan jika faktor internal ikut dalam mempengaruhi hasil akhir prosespembelajaran peserta didik. Adapun yang dimaksud dari faktor internal adalah seperti faktor kelelahan masing-masing individu, keadaan jasmaniah, maupun faktor psikologis individu. Pada beberapa penelitian terdahulu telah dikaji bebrapa faktor internal yang berpengaruh terhadap hasil belajar, namun masih belum banyak yang meneliti pengaruh faktor psikologi peserta didik. Seperti penelitian yang dilakukan Aisyah et al. (2017)diketahuipeserta didik mendapatkan hasil belajar rendah salah satunya disebabkan oleh faktor intern dengan beberapa indikator yang digunakan masih terkategori kurang baik seperti indikator ketenangan, minat, bakat, dan motivasi. Dalam penelitian diatas belum dikaji mengenai faktor psikologi peserta didik, padahal menurut Mardatila (2017) terdapat pengaruh dari faktor psikologi peserta didik terhadap hasil belajar yang di dapatkan.

Dari hasil pengamatan yang dilakukan penulis, kondisi lingkungan sekolah di SMA Negeri 1 Sumberrejo cukup baik dalam menunjang proses pembelajaran peserta didik di sekolah, tampak secara fisik seperti kondisi gedung sekolah dan lingkungan alamnya cukup mendukung namun masih ada sedikit faktor yang menyebabkan ketidaknyamanan dalam belajar seperti suasana kelas yang panas apabila di siang hari sebab tidak adanya pendingin ruangan di masing-masing kelas, serta kurangnya fasilitas belajar mengajar yang masih belum lengkap di masing-masing kelas. Hal ini menyebabkansedikit gangguan dalam memberikan bahan pelajaran kepada peserta didik dan belajarnya akan terganggu. Berdasarkan wawancara dengan salah seorang guru mata pelajaran ekonomi di sekolah mengatakan jika sebagian besar peserta didik kelas XI IPS di SMA Negeri 1 Sumberrejo mendapatkan hasil belajar ekonomi yang masih rendah atau dibawah KKM.

Oleh karena hal tersebut peneliti akan melakukan penelitian baru terhadap beberapa faktor yang berpengaruh kepada hasil belajar yang sebelumnya belum pernah dikaji peneliti lain dengan harapan agar peserta didik menjadi lebih perhatian terhadap semua faktor yang nantinya dapat meningkatkan hasil belajar. Diketahui dari beberapa penelitian sebelumnya masih sedikit studi penelitian yang mengkaji faktor eksternal lingkungan sekolah dengan faktor internal psikologi secara bersamaan, dan kebanyakan dari penelitian terdahulu hanya mengkaji faktor-faktor seperti lingkungan keluarga, keadaan ekonomi keluarga, dan sebagainya. Di sisi lain, faktor internal juga memiliki pengaruh terhadap hasil belajar peserta didik. Faktor internal disini digolongkan menjadi tiga yaitu faktor jasmaniah, psikologi, dan kelelahan. Pada beberapa penelitian terdahulu peneliti lebih condong untuk meneliti faktor jasmaniah peserta didik yang meliputi kesehatan jasmani dari pada meneliti faktor psikologi. Dari kedua alasan tersebut peneliti akan menggabungkan dua faktor yang berasal dari eksternal dan internal secara bersamaan yaitu antara faktor lingkungan sekolah dengan faktor psikologi peserta didik terhadap hasil belajar ekonomi.

Berdasarkan asumsi diatas peneliti berkeinginan melakukan studi penelitian lanjutan untuk melengkapi beberapa penelitian terdahulu agar mendapatkan hasil penelitian baru yang 
lebih lengkap dalam mengkaji beberapa faktor yang memiliki pengaruh terhadap hasil belajar dengan mengangkat judul "Pengaruh Lingkungan Sekolah dan Faktor Psikologi Peserta Didik Terhadap Hasil Belajar Mata Pelajaran Ekonomi Kelas XI IPS SMA Negeri 1 Sumberrejo"

\section{METODE PENELITIAN}

Dalam melaksanakan penelitian ini, peneliti menentukan jenis penelitian yaitu penelitian kuantitatif dan menggunakan metode penelitian korelasi. Dipilihnya metode korelasi karena ingin mencari hubungan dua variabel atau lebih yang bersifat kuantitatif yaitu variabel independen Lingkungan Sekolah (X1) dan Faktor Psikologi (X2) terhadap varibael dependen yaitu Hasil Belajar (Y).

Yang menjadi populasi pada penelitian ini adalah semua peserta didik kelas XI IPS SMA Negeri 1 Sumberrejo, Bojonegoro. Jumlah populasi pada penelitian ini berjumlah 135 peserta didik, dimana jumlah tersebut tersebar mulai dari kelas XI IPS 1 sebanyak 34 peserta didik, XI IPS 2 sebanyak 33 peserta didik, XI IPS 3 sebanyak 34 peserta didik, dan terakhir dari kelas XI IPS 4 sebanyak 34 peserta didik. Dari jumlah populasi tersebut semua nya akan dijadikan sebagai sampel penelitian yang berjumlah 135 peserta didik. Berikut jumlah sampel dari masing-masing kelas.

Tabel 1. Jumlah Sampel

\begin{tabular}{|c|c|c|}
\hline Kelas & $\begin{array}{c}\text { Jumlah } \\
\text { Peserta Didik }\end{array}$ & $\begin{array}{c}\text { Jumlah } \\
\text { Sampel }\end{array}$ \\
\hline XI IPS 1 & 34 & 34 \\
\hline XI IPS 2 & 33 & 33 \\
\hline XI IPS 3 & 34 & 34 \\
\hline XI IPS 4 & 34 & 34 \\
\hline \multicolumn{2}{|c|}{ Jumlah } & 135 \\
\hline
\end{tabular}

Sumber: Diolah Peneliti, 2021

Sementara itu perolehan sumber data primer yang digunakan dalam penelitian ini berasal dari kuesioner pengaruh lingkungan sekolah dan faktor psikologi terhadap hasil belajar yang diisi oleh peserta didik. Dan untuk perolehan sumber data sekunder dalam penelitian ini berasal dari nilai ujian akhir semester peserta didik.

Indikator yang dipakai dalam kuesioner lingkungan sekolah berdasarkan López et al. (2018)terdiri dari : lingkungan fisik sekolah, hubungan guru dengan peserta didik, hubungan peserta didik dengan peserta didik, serta orientasi guru terhadap pembelajaran. Sedangkan untuk indikator faktor psikologi berdasarkan Hazan Liran \& Miller (2019) terdiri dari : efikasi diri, harapan, optimisme, serta ketahanan. Skala yang dipakai untuk mengukur pada penelitian ini adalah skala likert. Dan data hasil belajar yang dipakai adalah nilai penilaian akhir semester gasal peserta didik kelas XI IPS SMA Negeri Sumberrejo tahun ajaran 2020/2021.

Dalam pengujian hipotesis digunakan statistik regresi linier bergandadan sebelumnya telah melewati uji persyaratan analisis seperti uji normalitas, multikolinieritas, dan heteroskedastisitas terlebih dahulu. Dalam analisis data tersebut digunakan aplikasi SPSS Statistic21. 


\section{HASIL DAN PEMBAHASAN}

\section{Deskripsi Data}

Untuk memperoleh data yang dibutuhkan pada penelitian ini adalah dengan menggunakan dokumentasi nilai Penilaian Akhir Semester Gasal 2020/2021 serta kuesioner yang diberikan kepada semua peserta didik di empat kelas XI IPS yang menjadi populasi di penelitian ini. Dimana masing-masing kelas diambil sebanyak 25 peserta didik sebagai sampel sehingga mendapatkan total sampel sebanyak 100 peserta didik. Hasil kuesioner yang diperoleh menggambarkan kondisi lingkungan sekolah dan faktor psikologis dari peserta didik yang menjadi populasi dari penelitian ini. Kuesioner yang diberikan terdiri dari 15 pertanyaan mengenai lingkungan sekolah dan 16 pertanyaan faktor psikologis peserta didik yang diukur menggunakan skala 4 pilihan jawaban yaitu jawaban sangat setuju memperoleh skor 4 , jawaban setuju memperoleh skor 3, jawaban tidak setuju memperoleh skor 2, dan jawaban sangat tidak setuju akan memperoleh skor 1. Kemudian semua data tersebut dilakukan analisis menggunakan bantuan software SPSS untuk mengetahui pengaruh lingkungan sekolah dan faktor psikologis peserta didik terhadap hasil belajar ekonomi kelas XI IPS SMA Negeri 1 Sumberrejo.

\section{Deskripsi data lingkungan sekolah}

Pada penelitian ini kuesioner yang dipakai untuk dapat melihat pengaruh dari lingkungan sekolah terhadap hasil belajar belajar terdiri dari 15 pertanyaan dengan menggunakan skala empat pilihan jawaban. Berdasarkan perolehan jawaban kuesioner lingkungan sekolah yang didapat dari 135 responden, diperoleh jawaban tertinggi yaitu 56\% menyatakan sangat setuju, sedangkan pilihan jawaban terendah adalah sebesar $1 \%$ yaitu menyatakan sangat tidak setuju. Sementara untuk sisanya 5\% menyatakan tidak setuju dan $38 \%$ setuju.

\section{Deskripsi data faktor psikologi}

Pada penelitian ini kuesioner yang dipakai untuk mengetahui pengaruh faktor psikologi peserta didik terhadap hasil belajar terdiri dari 16 pertanyaan dengan menggunakan skala empat pilihan jawaban. Berdasarkan perolehan jawaban kuesioner faktor psikologi peserta didik yang didapat dari 135 responden, diperoleh jawaban tertinggi yaitu 46\% menyatakan setuju, sedangkan pilihan jawaban terendah adalah sebesar $1 \%$ yaitu menyatakan sangat tidak setuju. Sementara untuk sisanyasebesar 9\% responden menyatakan tidak setuju dan $44 \%$ responden menyatakan sangat setuju.

\section{Deskripsi data hasil belajar}

Sumber data hasil belajar dalam penelitian ini didapatkan dari nilai Penilaian Akhir Semester mata pelajaran ekonomi peserta didik kelas XI IPS SMA Negeri 1 Sumberrejo Tahun Gasal 2020/2021. Berdasarkan perolehan data hasil belajar yang didapat dari 135 responden, diketahui bahwa sebanyak 101 peserta didik memperoleh nilai dibawah KKM atau dibawah 75 sedangkan 34 peserta didik mendapatkan nilai diatas KKM atau diatas 75 .

\section{Hasil Uji Persyaratan Analisis}

\section{Uji Normalitas}

Setelah melewati pengujian prasyarat analisis uji normalitas dengan syarat apabila nilai Asymp. Sig. (2-tailed) > $0.05(5 \%)$ data dikatakan terdistribusi normal, maka dari hasil pengujian diketahui nilai Asymp. Sig. (2-tailed) sebesar 0,241>0,05. Dengan demikian diambil kesimpulan jika semua data pada penelitian ini terdistribusi normal. 


\section{Uji Multikolinieritas}

Hasil uji prasyarat analisis multikolinieritas menunjukkan bahwa lingkungan sekolah dan faktor psikologi memiliki nilai Tolerance 0,774>0,10 dan nilai VIF sebesar 1,293< 10 sehingga dengan demikian dapat diambil kesimpulan jika semua datayang digunakan dalam penelitian ini bebas dari multikolinieritas.

\section{Uji Heteroskedastisitas}

Hasil uji prasyarat analisis heteroskedastisitasmenunjukkan bahwa nilai signifikansi variabel lingkungan sekolah sebesar 0,133>0,05 dan variabel faktor psikologi sebesar $0,102>0,05$ Dengan demikian diambil kesimpulan jika nilai residualyang digunakan dalam penelitian ini tidak terjadi heteroskedastisitas.

\section{Uji Hipotesis}

Uji $t$

Uji t digunakan untuk melihat pengaruh dari lingkungan sekolah dan faktor psikologi terhadap hasil belajar secara parsial. Jika nilai signifikansi $<0,05$ atau $t$ hitung lebih besar dari $t$ tabel $(1,977)$ maka dapat dikatakan terdapat pengaruh secara parsial lingkungan sekolah dan faktor psikologi terhadap hasil belajar. Berdasarkan hasil uji t menunjukkan bahwa $t$ hitung lingkungan sekolah sebesar 4,600 >1,977 sedangkan untuk t hitung faktor psikologi sebesar 4,183 > 1,977. Dari hasil tersebut maka dapat dikatakan bahwa lingkungan sekolah dan faktor psikologi secara parsial berpengaruh terhadap hasil belajar.

\section{Pengaruh lingkungan sekolah terhadap hasil belajar ekonomi yang didapatkan peserta didik kelas XI IPS SMA Negeri 1 Sumberrejo}

Setelah dilakukan beberapa pengujian seperti uji analisis dan uji hipotesis maka didapatkan hasil bahwa lingkungan sekolah berpengaruh terhadaphasil belajar ekonomi di kelas XI IPS SMA Negeri 1 Sumberrejo. Berdasarkan uji $\mathrm{t}$ didapatkan nilai $\mathrm{t}$ hitung pada variabel lingkungan sekolah sebesar 4,600> 1,977 maka dapat dikatakan bahwa lingkungan sekolah memiliki pengaruh terhadap rendahnya hasil belajar mata pelajaran ekonomi yang didapatkan oleh peserta didik yang berarti bahwa hipotesis satu diterima.

Berdasarkan temuan tersebut maka dapat dilihat bahwasanya banyak faktor eksternal yang dapat mempengaruhi hasil belajar, salah satunya adalah faktor lingkungan sekolah dimana tempat peserta didik menjalankan aktivitas belajar mengajar. Hal tersebut sejalan dengan apa yang dikatakan olehPeterria \& Suryani (2016)dalam penelitiannya bahwa ada pengaruh yang positif dan signifikan secara parsial variabel lingkungan sekolah terhadap hasil belajar.

Dalam mencapai keberhasilan belajar banyak ditemukan faktor-faktor yang menghambat proses belajar siswa baik dari eksternal maupun internal. Penelitian yang dilakukanAisyah et al.(2017)mengatakan bahwa sekolah dalam hal ini guru telah mengupayakan untuk membantu peserta didik dengan hasil belajar yang masih rendah agar mampu memperbaiki menjadi lebih baik, akan tetapi terlihat dari sisi peserta didik seperti kurang ada semangat untuk berubah, hal tersebut bisa saja disebabkan karena faktor orang tua yang kurang dalam memberikan perhatian dan dukungan serta fasilitas yang dibutuhkan peserta didik untuk menunjang kegiatan belajarnya.

Hasil belajar yang rendah tersebut juga bisa diakibatkan oleh adanya hambatan yang dialami oleh peserta didik. Hal itu juga disebabkan dari beberapa faktor, salah satunya adalah lingkungan sekolah. Penelitian oleh Latief (2016)mengatakan jika pengaruh lingkungan terhadap hasil belajar peserta didik cukup besar, karena sekolah adalah lingkungan sosial kedua 
setelah keluarga yang akan dikenal oleh peserta didik. Peserta didik lain di sekolah yang memiliki sifat rajin atau memiliki hasil belajar yang baik, tentu akan menjadi motivasi peserta didik untuk meningkatkan hasilnya dengan tujuan bisa setara atau bahkan melebihi temantemannya.Hal tersebut sejalan dengan yang dikatakan oleh Oktaviana (2015)dalam penelitiannya bahwasanya terdapat pengaruh positif dari lingkungan sekolah terhadap motivasi belajar yang artinya bahwa semakin positif pengaruh yang diberikan lingkungan sekolah terhadap proses pembelajaran yang dilakukan oleh peserta didik tentu akan sangat memotivasi serta membantu dalam upaya meningkatkan hasil belajar nya.

Berdasarkan beberapa pembahasan diatas dapat disimpulkan bahwasanya lingkungan sekolah merupakan salah satu faktor eksternal yang memiliki pengaruh terhadap hasil belajar yang didapatkan peserta didik. Hasil ini sejalan dengan teori dari Slameto (2010)bahwaada beberapa faktor yang memiliki pengaruh terhadap hasil belajar dan dari faktor-faktor tersebut dikelompokkan kedalam faktor ekstern dan faktor intern.Dalam hal ini lingkungan sekolah termasuk kedalam salah satu faktor ekstern.Utama et al. (2015) juga mengatakan bahwa salah satu dari beberapa faktor eksternal yang berpengaruh terhadap hasil belajar adalah lingkungan sekolah.

\section{Pengaruh faktor psikologi terhadap hasil belajar ekonomi yang didapatkan peserta didik kelas XI IPS SMA Negeri 1 Sumberrejo}

Setelah dilakukan beberapa pengujian seperti uji analisis dan uji hipotesis diketahui bahwa faktor psikologi berpengaruh terhadap hasil belajar ekonomi di kelas XI IPS SMA Negeri 1 Sumberrejo. Berdasarkan uji t didapatkan nilai t hitung pada variabel faktor psikologi sebesar 4,183 > 1,977 maka disimpulkan bahwasanya faktor psikologi memiliki pengaruh terhadap hasil belajar mata pelajaran ekonomi yang didapatkan oleh peserta didik kelas XI IPS SMA Negeri 1 Sumberrejo yang berarti bahwa hipotesis dua diterima. Dengan ini maka dapat disimpulkan apabila faktor psikologi peserta didik baik maka hasil belajar yang akan didapatkan oleh peserta didik juga akan baik. Sesuai dengan teori yang dikemukakan oleh Slameto (2010)jika hasil belajar dipengaruhi oleh salah satunya dari faktor internal yaitu faktor psikologi.

Hasil penelitian ini juga sependapat dengan penelitian terdahulu yang dilakukan olehAisyah et al. (2017) yang menganalisis faktor penyebab hasil belajar peserta didik yang rendah salah satunya disebabkan oleh faktor psikologi dengan indikator seperti minat, bakat, konsentrasi, dan motivasi dari dalam diri peserta didik yang terkategori masih cukup rendah. Dengan demikian apabila menginginkan hasil belajar yang lebih maksimal maka sangat diperlukan koordinasi dari pihak sekolah dengan orang tua maupun dengan peserta didik itu sendiri agar dapat memberikan motivasi lebih terhadap peserta didik sehingga dapat memperbaiki faktor-faktor yang berkaitan dengan keadaan psikologi peserta didik. Faktor psikologis disini merupakan kondisi mental yang sulit diketahui oleh orang lain, sebab hal tersebut berada di dalam diri peserta didik masing-masing. Ketika belajar peserta didik sangat memerlukan suatu kesiapan dan ketenangan. Kemudian jika peserta didik tidak memiliki kesiapan dan ketengan maka hal tersebut akan berdampak terhadap pembelajaran sehingga mereka kesulitan untuk menerima materi. Oleh sebab itu perlu dukungan dari banyak pihak agar peserta didik memiliki keadaan psikologis yang baik guna dapat mencapai tujuan akhir dari kegiatan belajar yaitu mendapatkan hasil belajar yang baik.

Temuan yang sama juga didapatkan oleh Mardatila (2017)dalam penelitiannya yang menyarankan agar pihak sekolah dengan orang tua peserta didik agar selalu bekerja sama dalam melakukan diagnosa dan bimbingan yang rutin kepada peserta didik dengan hasil belajar yang masih rendah agar mereka lebih termotivasi dan dapat mencapai hasil belajar yang tinggi. 
Selain itu penelitian olehHariyani (2018) mengatakan bahwa dalam menentukan topik pelajaran yang sesuai, guru perlu mempertimbangkan terhadap keadaan psikologi peserta didik agar dalam melaksanakan kegiatan belajar mengajar peserta didik mampu dengan mudah dalam memahami materi yang disampaikan oleh guru.

Pendapat yang sama juga dikemukakan olehHerawati \& Widiastuti (2016)melalui penelitiannya yang mendapatkan hasil bahwa faktor psikologi merupakan bagian dari salah satu faktor internal yang berpengaruh terhadap hasil belajar. Faktor psikologi yang dimaksud adalah situasi dan kondisi yang berasal dari dalam diri atau pikiran peserta didik itu sendiri. Faktor psikologi yang dimaksud dalam penelitiannya terdiri dari kecerdasan emosional, perhatian, kebiasaan belajar, sikap, kesiapan, dan modernitas individu.

Dari pembahasan diatas dapat diambil kesimpulan apabila menginginkan hasil belajar yang baik maka salah satu faktor yang harus ditingkatkan adalah faktor psikologi peserta didik. Sebab menurut Goleman (2004)Kondisi dari dalam diri seseorang adalah faktor yang berperan sangat besar dalam menentukan prestasi.

\section{KESIMPULAN}

Dari hasil analisis dan uji hipotesis yang sudah peneliti lakukan serta penjelasan yang telah peneliti uraikan mengenai beberapa faktor yang berpengaruh terhadap hasil belajar maka didapatkan kesimpulan sebagai berikut:

1. Terdapat pengaruh dari lingkungan sekolah terhadap hasil belajar mata pelajaran ekonomi peserta didik kelas XI IPS SMA Negeri 1 Sumberrejo. Sehingga lingkungan sekolah perlu memberikan dukungan yang maksimal terhadap peserta didik agar mereka lebih bersemangat dalam mengikuti proses pembelajaran yang nantinya dapat meningkatkan hasil belajar nya.

2. Terdapat pengaruh dari faktor psikologi terhadap hasil belajar mata pelajaran ekonomi peserta didik kelas XI IPS SMA Negeri 1 Sumberrejo. Hal tersebut berarti salah satu faktor intern yang perlu lebih diperhatikan oleh peserta didik agar mendapatkan hasil belajar yang baik adalah faktor psikologi.

3. Pada penelitian ini baru dibahas dua faktor yang berkaitan terhadap hasil belajar peserta didik, sehingga masih terdapat beberapa faktor lain yang dapat di kaji lebih lanjut sehingga akan melengkapi penelitian ini maupun penelitian terdahulu.

Untuk penelitian selanjutnya alangkah lebih baiknya menggunakan variabel yang berbeda dari penelitian ini guna lebih memperluas hasil penelitian yang didapatkan sehingga dapat membantu memberikan masukan kepada pihak-pihak terkait. Bagi pihak sekolah diharapkan untuk selalu berkoordinasi dengan orang tua peserta didik agar senantiasa melakukan bimbingan dan dukungan sehingga peserta didik memiliki semangat untuk terus meningkatkan hasil belajarnya. Bagi peserta didik sendiri agar lebih optimal dalam mengikuti proses belajar di lingkungan sekolah dan lebih memperhatikan faktor-faktor psikologinya agar dapat meningkatkan hasil belajarnya. Selanjutnya, Bagi orang tua agar senantiasa memberikan dorongan belajar kepada anaknya serta selalu memantau perkembangan hasil belajar di sekolah sehingga anak merasa lebih diperhatikan oleh orang tua yang nantinya dapat meningkatkan keadaan psikologi mereka. 


\section{DAFTAR PUSTAKA}

Aisyah, Jaenudin, R., \& Koryati, D. (2017). Analisis Faktor Penyebab Rendahnya Hasil Belajar Peserta Didik pada Mata Pelajaran Ekonomi di SMA Negeri 15 Palembang. Jurnal Profit, 4(1), 1-11.

Araimi, M., \& Fitra, H. (2015). Pengaruh Lingkungan Keluarga Terhadap Prestasi Belajar Siswa Kelas XI Sma Negeri 3 Peusangan. Jurnal Sains Ekonomi Dan Edukasi, III(2), 18. fkip.umuslim.ac.id/index.php/jsee/article/download/264/158

Chulsum, U. (2017). Pengaruh Lingkungan Keluarga, Kedisiplinan Siswa, Dan Motivasi Belajar Terhadap Hasil Belajar Ekonomi Siswa Di Sma Negeri 7 Surabaya. Jurnal Ekonomi Pendidikan Dan Kewirausahaan, $5(1), \quad 5$. https://doi.org/10.26740/jepk.v5n1.p5-20

Dewi, R., \& Marwan. (2019). Pengaruh Faktor Fisiologis, Lingkungan Sekolah, dan Motivasi Belajar Terhadap Hasil Belajar Ekonomi Di SMAN 2 Painan. Jurnal Ecogen, 2(4), 696. https://doi.org/10.24036/jmpe.v2i4.7847

Goleman, D. (2004). Emotional Intelligence, Kecerdasan Emosional Mengapa EI Lebih Penting daripada IQ. PT. Gramedia Pustaka Utama.

Hariyani, Y. (2018). Peran Penting Psikologis terhadap Peserta Didik SD melalui Pembelajaran Tematik-Terpadu. Edureligia; Jurnal Pendidikan Agama Islam, 2(2), 70-76. https://doi.org/10.33650/edureligia.v2i2.456

Hazan Liran, B., \& Miller, P. (2019). The Role of Psychological Capital in Academic Adjustment Among University Students. Journal of Happiness Studies, 20(1), 51-65. https://doi.org/10.1007/s10902-017-9933-3

Herawati, I., \& Widiastuti, Y. (2016). Analisis Faktor-Faktor Yang Mempengaruhi Prestasi Belajar Akuntansi. Journal of Accounting and Business Education, 1(3), 1-13. https://doi.org/10.26675/jabe.v1i3.6028

Khafid, M., \& Suroso. (2007). Pengaruh Disiplin Belajar Dan Lingkungan Keluarga Terhadap Hasil Belajar Ekonomi. Jurnal Pendidikan Ekonomi, 2(2), 185-204. https://doi.org/10.15294/dp.v2i2.447

Latief, A. (2016). Pengaruh lingkungan sekolah terhadap hasil belajar pendidikan kewarganegaraan pada peserta didik di smk negeri paku kecamatan binuang kabupaten polewali ... Pepatudzu: Media Pendidikan Dan Sosial ..., 7(1), 13-26. https://journal.lppm-unasman.ac.id/index.php/pepatudzu/article/view/11

López, V., Torres-Vallejos, J., Ascorra, P., Villalobos-Parada, B., Bilbao, M., \& Valdés, R. (2018). Construction and validation of a classroom climate scale: a mixed methods approach. Learning Environments Research, 21(3), 407-422. https://doi.org/10.1007/s10984-018-9258-0

Mardatila, A. P. (2017). Pengaruh Faktor Psikologis dan Faktor Sekolah Terhadap Hasil Belajar Siswa Kelas VII Pada Mata Pelajaran IPS Tematik Terpadu Di SMP Negeri 1 Tanjungsari.

Sulaeman, M. M. (2020). Sosialisasi Kewirausahaan dalam Upaya Peningkatan UMKM Desa Palangan Kecamatan Karangbinangun Kabupaten Lamongan. Jurnal Abdimas Berdaya: Jurnal Pembelajaran, Pemberdayaan dan Pengabdian Masyarakat, 2(01), 16-22.

Oktaviana, I. (2015). Pengaruh Lingkungan Sekolah terhadap motivasi belajar siswa kelas V Sekolah Dasar di daerah Binaan I Kecamatan Limpung Kabupaten Batang. Universitas Negeri Semarang.

Peterria, V., \& Suryani, N. (2016). Pengaruh Lingkungan Sekolah, Cara Belajar, Dan Motivasi Belajar Terhadap Hasil Belajar Siswa Pada Mata Pelajaran Mengelola Peralatan. Economic Education Analysis Journal, 5(3), 860-860. 
Rohwati, M. (2012). Penggunaan Education Game Untuk Meningkatkan Hasil Belajar IPA Biologi Konsep Klasifikasi Makhluk Hidup. Jurnal Pendidikan IPA Indonesia, 1(1), 7581.

Slameto. (2010). Belajar dan Faktor-faktor yang Mempengaruhinya. PT Rineka Cipta.

yairozi, M. I. (2019). Pengungkapan CSR pada Perusahaan Manufaktur dan Perbankan: Tidar Media. Tidar Media.

Utama, N., Subkhan, \& Nurkhin, A. (2015). Pengaruh Persepsi Siswa tentang Kompetensi Profesional Guru, Fasilitas Belajar, dan Lingkungan Sekolah Terhadap Hasil Belajar Akuntansi Kelas X Di Smk Muhammadiyah 1 Semarang. Economic Education Analysis Journal, 4(2), 376-388. 